\title{
Innovation and employment growth: evidence from manufacturing firms in Africa
}

\author{
Ibrahim Mike Okumu ${ }^{1 *}$, Edward Bbaale ${ }^{1}$ and Madina Mwagale Guloba ${ }^{2}$
}

\footnotetext{
* Correspondence: okumuim@gmail. com

${ }^{1}$ School of Economics, Makerere University, Kampala, Uganda

Full list of author information is

available at the end of the article
}

\begin{abstract}
This paper estimates the association between innovation and employment growth among manufacturing firms in Africa. The paper uses a cross-sectional World Bank Enterprise Survey dataset in which innovation is categorised as product innovation and process innovation. Results from the pooled ordinary least squares (OLS) estimation are more efficient compared to IV 2SLS. The pooled OLS results indicate that: (1) employment growth is positively associated with both process and product innovation, (2) a weak business environment especially intermittent electricity supply undermines the ability of innovation to induce employment growth and (3) relationship between innovation and employment growth is not conditioned on firm age although it is conditioned on firm size. Such findings suggest that employment growth in Africa could benefit from policies and programs that induce firms to embrace innovation. In addition, a strong business environment is necessary in complementing the potential of innovation to enhance employment growth in Africa.

Keywords: Employment, Product innovation, Process innovation, Africa

JEL classification: D2, J23, O31, O33, O55
\end{abstract}

\section{Introduction}

Economic progress is partly tied to innovation. Innovation in the Schumpeterian perspective is referred to as a creative destruction implying that new ways of production, organisational management and products are being churned out rendering old ones obsolete. As such, an economy's growth dynamics is attributed to creative destruction (Aghion and Howitt 1992). The neoclassical growth model assumes that an economy grows at its natural rate in the long run because of diminishing returns; however, introducing innovation into the model undermines this assumption (Aghion and Akcigit 2017). Hence, innovation is central to an economy's economic growth dynamics and by extension to employment growth dynamics in both the short and long run.

Following the Arab Spring-partly attributed to lack of economic participation space among youths-policy makers in Africa have somewhat focused on how to address unemployment. Note that the overall unemployment rate is $7.3 \%$ and $10.5 \%$ in sub-Saharan Africa (SSA) and Middle East and North African (MENA) countries,

( ) The Author(s). 2019 Open Access This article is distributed under the terms of the Creative Commons Attribution 4.0 International License (http://creativecommons.org/licenses/by/4.0/), which permits unrestricted use, distribution, and reproduction in any medium, provided you give appropriate credit to the original author(s) and the source, provide a link to the Creative Commons license, and indicate if changes were made. 
respectively (WDI, 2018). Among youths between 15 and 24 years, unemployment rate is $14.2 \%$ and $28.1 \%$ in SSA and MENA countries, respectively (World development Indicators, 2018). Evidently, unemployment in Africa is still a glaring challenge necessitating solution(s) identification to abate scenes reminiscent of the Arab Spring.

From the foregoing perspective, one can question whether innovation can unlock Africa's unemployed labour force into productive economic participation? In essence, can innovation result into employment growth in Africa? The preceding question is core to this paper. Since Africa is far from the technological frontier besides research and development (R\&D) being an expensive and risky venture, its innovation is largely characterised by imitation ${ }^{1}$ (Naudé et al. 2011). However, whether innovation has resulted into employment growth in Africa is an open question. In this paper, innovation can be process ${ }^{2}$ or product ${ }^{3}$ innovation.

Empirical evidence on the relationship between innovation and employment growth is inconclusive especially with regard to whether employment growth is associated with process innovation. For example, there is consensus in the developed world literature that employment growth is directly associated with product innovation (Harrison et al. 2014; Bogliacino et al. 2012; Lachenmaier and Rottmann 2011; Meriküll, 2010; Peters 2004; Greenan and Guellec 2000). However, the debate is still open with regard to the relationship between process innovation and employment growth. For example, Harrison et al. (2014), Lachenmaier and Rottmann (2011) and Greenan and Guellec (2000) argue that employment growth is positively associated with process innovation while Peters (2004) finds a direct relationship between employment growth and process innovation. However, Evangelista and Vezzani (2012) show that employment growth is inversely related with process innovation.

While the related literature from developing countries is scanty, even then there is consensus that employment growth is positively associated with product innovation in Latin America (Elejalde et al. 2015; Aboal et al. 2015; Benavente and Lauterbach 2008). However, the relationship between employment growth and process innovation is equally inconclusive. For example, Elejalde et al. (2015) and Benavente and Lauterbach (2008) argue that employment growth is not associated with process innovation. Aboal et al. (2015) further argue that employment growth is only inversely related to process innovation among unskilled labour workers although the relationship is neutral among skilled workers. On the contrary, Cirera and Sabetti (2016) show that employment growth is directly related with process innovation.

From the foregoing, empirical debate suggests that the relationship between innovation and employment growth is rather an open question especially with regard to the effect of process innovation on employment growth. This paper therefore seeks to contribute to this debate by using manufacturing firm-level data across 27 African countries in four ways. First, the paper explains the relationship between process and product innovation and employment growth. Secondly, it identifies the existence of complementarity effects between process and product innovation in their relationship with employment growth. This follows Evangelista and Vezzani (2012) who show that the strongest impact of innovation on employment growth is experienced when firms combine process, organisational and product innovations. ${ }^{4}$ Thirdly, the paper tries to understand whether the relationship between process and product innovation and employment growth is uniform across firm sizes and age. Finally, analysis is made on 
whether the relationship between innovation and employment growth is undermined by a weak business environment on employment growth. Therefore, the following hypotheses are tested: (1) employment growth is positively associated with process and product innovation; (2) both process and product innovation complement each other in how they relate with employment growth; and (3) the relationship between innovation and employment growth is conditioned on firm age, firm size and the business environment.

The paper is similar to other papers that have used firm-level data to explain employment growth in Africa. For example, Bhaumik et al. (2007) in a study of employment growth among firms in Egypt, India, South Africa and Vietnam shows that where firms are $100 \%$ foreign owned, employment growth is higher. Furthermore, using a sample of 19 SSA countries, Coniglio et al. (2015) show that whereas foreign-owned firms are generally larger than domestically owned firms, they unfortunately create more unskilled labour employment compared to domestically owned firms. Also, Chinese firms are more likely to employ manual workers compared to other foreign-owned firms and domestically owned firms (Coniglio et al. 2015). This paper is also similar to Aterido et al. (2011) who show that employment growth among firms in developing countries is positively associated with the quality of business environment.

The rest of the paper is structured as follows: the "Literature review" section captures the empirical literature. The "Methods" section presents the estimation strategy, data description and models estimated. The "Results and discussion" section presents and discusses results from the preferred empirical models. The "Conclusion and policy implications" section captures the conclusions.

\section{Literature review}

\section{Product innovation and employment growth}

There is consensus that employment growth is positively associated with product innovation at least in developed and Latin American economies. For example, using a multi-product model, Peters (2004) in a study of 2200 Germany firms observed over the period 1998-2000 shows that employment growth is associated with product innovation with a higher effect among manufacturing and larger firms. Consistent with Peters (2004) using the two-period and two-good production model, Harrison et al. (2014) in a study of 20,000 firms from France, Germany, Spain and the UK over the period 1998-2000 show that employment growth is positively associated with product innovation.

Furthermore, using a longitudinal database of 677 European manufacturing and service firms, Bogliacino et al. (2012) test the effect of R\&D on employment. They find that employment growth is positively associated with firm expenditure in R\&D biased towards product innovation among services and high-tech manufacturing firms. Finally, Fukao et al. (2017) find similar results while using microdata from the Basic Survey of Japanese Business Structure and Activities with R\&D expenditure as a proxy for product innovation.

\section{Process innovation and employment growth}

The relationship between process innovation and employment growth is inconclusive. For example, Harrison et al. (2014) show that employment growth is positively 
associated with process innovation while Evangelista and Vezzani (2012) and Peters (2004) show that employment growth is negatively related with process innovation.

More specifically, Meriküll (2010) in a study of firms in Estonia shows that employment growth is directly related with process innovation among medium and low-tech industries. Furthermore, using a dataset of 15,186 French manufacturing firms over the period 1986-1990, Greenan and Guellec (2000) show that employment growth is positively associated with innovating firms over the medium term. Specifically, process innovation creates more jobs compared to product innovation (Greenan and Guellec 2000).

Also, Lachenmaier and Rottmann (2011) using a systems GMM methodology applied on a panel dataset of German manufacturing firms covering a period of at least 20 years show that employment growth is positively associated with both process and product innovation. Most importantly though is that process innovation has a higher impact on employment growth than product innovation (Lachenmaier and Rottmann, 2011). In addition, using the Community Innovation Survey dataset of 65,118 firms from Czech Republic, France, Spain, Italy, Portugal and Slovenia collected over the period 20022004, Evangelista and Vezzani (2012) show that employment growth is positively associated with innovation among firms that combine process, organisational and product innovations.

With regard to the developing world, evidence in Latin America is similar to that found for the developed world. Indeed, there is consensus in Latin American studies that employment growth is positively associated with product innovation. However, the relationship between employment growth and process innovation is equally inconclusive with cases of inverse and neutral association apparent. For example, using a sample of 1415 firms in Argentina, Elejalde et al. (2015) show that product innovation has a positive effect on employment growth; however, the effect of process innovation on employment growth is neutral. Relatedly, Benavente and Lauterbach (2008) in a study of firms in Chile show that employment growth is positively associated with product innovation although neutral to process innovation. Similarly, Aboal et al. (2015) in a study of Uruguayan manufacturing firms shows that product innovation enhances employment growth; however, process innovation reduces employment growth among unskilled labour although its neutral for skilled labour.

However, with regard to studies relating employment growth and innovation in Africa, these are rather scarce. Indeed, other than Cirera and Sabetti (2016), no other study has estimated the relationship between innovation and employment in Africa. Yet even Cirera's and Sabetti's (2016) focus is not on Africa alone. The authors extend their work with a sample of 15,000 firms to cover other continents besides Africa such as South Asia, Middle East and North Africa, Eastern Europe and Central Asia to explain the relationship between innovation and employment growth. They find that process innovation is positively associated with employment growth (ibid). To add to the debate on Africa, this paper, however, is different from Cirera and Sabetti (2016) in two ways. First, it attempts to understand whether the effect of innovation on employment growth is undermined by a weak business environment. Secondly, it attempts to study the effect of innovation on employment growth when a firm engages in both product and process innovation in comparison to when a firm that engages in either product or process innovation or no innovation. Finally, it endeavours to understand whether the relationship between innovation and employment growth is mediated by 
size and age of the firm. In Africa, firm-level studies on innovation and employment growth dynamics are rather in their nascent stage, hence the need for this paper to narrow this gap.

Overall, the empirical literature indicates that the relationship between process innovation and employment growth is rather inconclusive. With regard to the relationship between product innovation and employment, there is consensus in the developed world and Latin American empirical literature that employment growth is positively associated with product innovation.

\section{Methods}

\section{Estimation strategy}

Process innovation typically has a direct effect on firm productivity and therefore unit costs. This induces price reduction of a firm's product which leads to increased demand for the product. Higher demand for the product could lead to more output which potentially results in capacity expansion thus employment growth. Product innovation on the other hand is associated with product demand enhancement thus the need for a firm to adjust output upwards which potentially induces capacity expansion thus employment growth (Harrison et al. 2014).

However, note that the extent of price adjustment following process or product innovation and ultimately output and employment growth partly depends on two conditions. First is the market structure within which a firm operates. Second is the speed of adjustment with which competitors improve their production processes or introduce new products (Nickell 1999 in Harrison et al. 2014). Unfortunately, out of the 6400 firms in the World Bank Enterprise Survey (WBES) sample this paper uses, only 29\% responded to the question regarding the number of competitors to the firm's main product. This constrained the ability to control for the level of competitiveness using the Herfindahl index in the empirical analysis. Furthermore, data regarding the speed of adjustment of competing firms in the event a firm introduces a new product or experiences price reductions attributed to efficiency gains resulting from process innovation is not available. For example, the cross-sectional nature of the innovation variables does not allow the possibility of using lagged values of innovation to account for speed of competitor adjustment (Piva and Vivarelli 2004, 2005).

With regard to product innovation, it is possible that the introduction of new products may reduce the market share of old products. In so doing, the net effect on the demand of a firm's product may remain unchanged or marginally change thereby inhibiting the ability of product innovation to induce output increase and thus employment growth. However, WBES does not distinguish between sales associated with new products or old products rather; it provides information about sales as an aggregate. As a result, this incapacitate the ability to control for the effect of product innovation through new product sales and consequently employment growth. Therefore, given data constraints, it is cumbersome to undertake a structural modelling approach to estimate the relationship between innovation and employment growth in Africa as used by Van Reenen (1997), Lachenmaier and Rottmann (2011) and Harrison et al. (2014) among European firms. Even then, following Evangelista and Vezzani (2012), this paper explores the association between innovation and employment 
growth among manufacturing firms in Africa by estimating Eq. 3.1 using pooled ordinary least squares technique.

$$
\mathrm{EG}_{\mathrm{ijc}}=\beta_{o}+\beta_{1} \Psi_{\mathrm{ijc}}+\beta_{2} K_{\mathrm{ijc}}+\beta_{3} B_{\mathrm{ijc}}+\beta_{4} \gamma_{\mathrm{ijc}}+\beta_{5} \delta_{\mathrm{ijc}}+\varepsilon_{\mathrm{ijc}}
$$

where $i, j$ and $c$ index firm, sector and country, respectively. $\Psi$ captures the innovation variable that is Innov, Process and Product. Where Innov is a categorical variable which captures the complementarity between process and product innovation. Process is a categorical variable capturing whether a firm undertook process innovation or not. Product is a categorical variable capturing whether a firm undertook product innovation or not. $K$ is a vector of firm specific characteristics. Consistent with Aterido and Hallward-Driemeier (2010), firm-specific characteristics include sales growth, labour productivity, nature of ownership, location, exporting and managerial experience.

$B$ is a vector of business environment characteristics. Consistent with Aterido and Hallward-Driemeier (2010), our business environment variables include electricity, bureaucracy, source of financing, bribe and competition. $\gamma$ is a dummy variable capturing country fixed effects. Similarly, we include $\delta$ which is a dummy variable capturing the International Standard Industrial Classification (ISIC) or industry fixed effects. While $\varepsilon$ is the error term which is assumed to have a zero-mean besides being identically and independently distributed across firms. Therefore, Eq. 3.1 captures the relationship between employment growth and innovation while controlling for business environment, firm specific characteristics, country fixed effects and ISIC fixed effects.

To understand whether innovation is associated with cannibalism as regards employment growth, ${ }^{5}$ then on one hand, it must be the case that $\beta_{1}<0$. Implying that, employment growth is inversely associated with innovation. On other the hand, if $\beta_{1}>0$, it implies that employment growth is directly associated with innovation. To measure complementarity effects between process and product innovation, our interest is on the size and direction of the coefficient when a firm uses either innovation modes or a combination of both. If $\beta_{1}>0$ when a firm engages in both product and process innovation compared to no innovation, then it follows that employment growth is directly associated with innovation when a firm engages in both innovation modalities hence existence of complementarity effects. Otherwise, when $\beta_{1}<0$, this implies that combinations of both process and product innovation are cannibalistic to employment growth in comparison to no innovation.

While if $\beta_{1}$ which is associated with a firm that chooses to use either process or product innovation is positive and significant compared to a non-innovating firm, it would suggest that irrespective of whether a firm chooses either innovation, employment growth is expected to increase. Besides the innovation variable, we shall equally estimate the employment growth using Process and Product as explanatory variables. In this case, if $\beta_{1}$ associated with Process is positive and significant, then employment growth is positively associated with process innovation. Also, if $\beta_{1}$ associated with Product is positive and significant, then employment growth is positively associated with product innovation. 
Furthermore, this paper is interested in understanding whether the relationship between innovation and employment growth is conditioned on firm size. In that regard, interactions are made between innovation variables with firm size as shown below;

$$
\begin{aligned}
\mathrm{EG}_{\mathrm{ijc}} & =\beta_{o}+\beta_{1} \Psi_{\mathrm{ijc}}+\beta_{2} \operatorname{Small}_{\mathrm{ijc}}+\beta_{3} \operatorname{Large}_{\mathrm{ijc}}+\beta_{4}\left(\Psi \times \text { Small }_{\mathrm{ijc}}\right. \\
& +\beta_{5}(\Psi \times \text { Large })_{\mathrm{ijc}}+\beta_{6} H_{\mathrm{ijc}}+\beta_{7} B_{\mathrm{ijc}}+\beta_{8} \gamma_{\mathrm{ijc}}+\beta_{9} \delta_{\mathrm{ijc}}+\varepsilon_{\mathrm{ijc}}
\end{aligned}
$$

where $H$ captures other firm specific characteristics. The interest of this paper is to show how different coefficients $\beta_{4}$ and $\beta_{5}$ are from $\beta_{2}$ and $\beta_{3}$, respectively. On one hand, if $\beta_{2}$ is for instance significantly negative while $\beta_{4}$ is significantly positive, then it would suggest that innovation ameliorates the negative effect of small firms on employment growth. On the other hand, if $\beta_{2}$ is significantly positive while $B_{4}$ is significantly negative, then it would suggest that employment growth is negatively associated with innovation among small firms. The same intuition holds for the interaction between innovation and large firms.

Using a sample of 31 SSA countries, Aterido and Hallward-Driermeier (2010) show that employment growth is more concentrated among young firms. As such, we estimate whether the relationship between employment growth and innovation is conditioned on firm age using Eq. 3.3.

$$
\begin{aligned}
\mathrm{EG}_{\mathrm{ijc}} & =\beta_{o}+\beta_{1} \Psi_{\mathrm{ijc}}+\beta_{2} \text { Young }_{\mathrm{ijc}}+\beta_{3} \text { Older }_{\mathrm{ijc}}+\beta_{4}(\Psi \times \text { Young })_{\mathrm{ijc}} \\
& +\beta_{5}\left(\Psi \times \text { Older }_{\mathrm{ijc}}+\beta_{6} Y_{\mathrm{ijc}}+\beta_{7} B_{\mathrm{ijc}}+\beta_{8} \gamma_{\mathrm{ijc}}+\beta_{9} \delta_{\mathrm{ijc}}+\varepsilon_{\mathrm{ijc}}\right.
\end{aligned}
$$

where $Y$ captures other firm-specific characteristics. Our interest is on how different coefficients $\beta_{4}$ and $\beta_{5}$ are from $\beta_{2}$ and $\beta_{3}$, respectively. If $\beta_{2}$ is for instance significantly negative while $B_{4}$ is significantly positive, then it would suggest that employment growth is increasing in innovation even among young firms. However, if $\beta_{2}$ is significantly positive while $\beta_{4}$ is significantly negative, then it would suggest that innovation is deleterious to employment growth among young firms. We hold a similar intuition for the interaction between innovation and older firms.

A weak business environment undermines employment growth (Aterido and Hallward-Driermeier 2010). Since innovation is associated with a reduction in the cost of production (efficiency gains), therefore using Eq. 3.4, we understand whether conditioned on a weak business environment, innovation has the potential to propagate employment growth.

$$
\mathrm{EG}_{\mathrm{ijc}}=\beta_{o}+\beta_{1} \Psi_{\mathrm{ijc}}+\beta_{2} B_{\mathrm{ijc}}+\beta_{3}(\Psi \times B)_{\mathrm{ijc}}+\beta_{4} K_{\mathrm{ijc}}+\beta_{5} \gamma_{\mathrm{ijc}}+\beta_{6} \delta_{\mathrm{ijc}}+\varepsilon_{\mathrm{ijc}}
$$

Note that if for instance $\beta_{2}$ is significantly negative while $\beta_{3}$ is significantly positive, then it would suggest that employment growth is positively associated with innovation irrespective of the business environment. That is innovation offsets the distortionary effect of a business environment on employment growth. However, if both $\beta_{2}$ and $\beta_{3}$ are significantly negative, then it would suggest that innovation does not offset the negative effect of a weak business environment on employment growth. 
Equations 3.1, 3.2, 3.3 and 3.4 are estimated using the pooled OLS. Note that because of the likelihood of endogeneity, since employment growth could result from a firm hiring new workers who could engage in $R \& D$, the effect of which could be new innovations. Or the newly hired workers could be for purposes of managing the implementation of the new innovations. Like in Dachs and Peters (2014) and Harrison et al. (2014), we instrument for process and product innovations using $R \& D$. $R \& D$ is a binary variable taking a value of ' 1 ' when a firm undertook R\&D otherwise ' 0 '. Unfortunately this paper does not disentangle $R \& D$ in terms of whether it was aimed at process or product innovation. As such, the R\&D variable is used as is to instrument process and product innovations. Furthermore, given that $R \& D$ is a risky and expensive venture, many developing countries typically engage in imitation rather than develop new ideas. As such, given data limitations, this paper uses R\&D as an instrument for process and product innovations (Naudé et al., 2011).

\section{Robustness tests}

$R \& D$ as an instrument passes the first test of explaining innovation decision of a firm as shown by the $p$ values at the first stage. However, at the second stage, we cannot reject the null hypothesis that process and product innovations are exogenous. Evidently, the Durbin and Wu-Hausman tests for endogeneity suggest that as opposed to instrumenting for process and product innovations using R\&D, pooled OLS estimations would offer better results for purposes of explaining the relationship between innovation and employment growth (Table 8). Unfortunately, while Dachs and Peters (2014) and Harrison et al. (2014) had alternative instruments-a variable that indicates whether the product innovation was aimed at increasing the product range-given data limitations, this alternative instrument is not possible for this paper. With this in mind, throughout this paper, results presented and analysed are based on the pooled OLS estimates with standard errors clustered at firm level.

\section{Data and variable description}

\section{Data and source}

The paper uses the World Bank Enterprise Survey dataset of 6400 manufacturing firms from 27 African countries ${ }^{6}$ (Table 1) that were eligible because they had innovation data. Note that the surveys were undertaken in different years in different countries. Both Rwanda and Central African Republic had the oldest dataset as the surveys were undertaken in 2011. The WBES dataset provides a representative sample of each country's firm performance indicators and business environment characteristics.

The sample frame is attained from a universe of eligible firms obtained from each country's statistical office. In the event of inadequacies, a master list of firms is attained from (1) other government agencies such as tax or business licensing authorities and (2) business associations or marketing databases. However, under rare occasions, the sample frame is created via block enumeration. The surveys target formal firms with five or more employees, and responses are solicited from business owners and top managers.

The ability to assess the relationship between innovation and employment growth is because in the WBES dataset, firms responded to the questions: (1) during the last 3 
Table 1 Number of firms by country

\begin{tabular}{|c|c|c|c|}
\hline Country & Year of survey & Frequency & Percent \\
\hline Ethiopia & 2015 & 348 & 5.44 \\
\hline Burundi & 2014 & 59 & 0.92 \\
\hline Uganda & 2013 & 316 & 4.94 \\
\hline Tanzania & 2013 & 317 & 4.95 \\
\hline Rwanda & 2011 & 74 & 1.16 \\
\hline Kenya & 2013 & 376 & 5.88 \\
\hline DRC & 2013 & 184 & 2.88 \\
\hline Djibouti & 2013 & 49 & 0.77 \\
\hline Egypt & 2016 & 1130 & 17.66 \\
\hline Cameroon & 2016 & 88 & 1.38 \\
\hline Central African Republic & 2011 & 34 & 0.53 \\
\hline Ivory Coast & 2016 & 97 & 1.52 \\
\hline Ghana & 2013 & 339 & 5.3 \\
\hline Guinea & 2016 & 20 & 0.31 \\
\hline Tunisia & 2013 & 312 & 4.88 \\
\hline Zambia & 2013 & 309 & 4.83 \\
\hline Sudan & 2014 & 82 & 1.28 \\
\hline Swaziland & 2016 & 65 & 1.02 \\
\hline Lesotho & 2016 & 69 & 1.08 \\
\hline Malawi & 2014 & 178 & 2.78 \\
\hline Mauritania & 2014 & 50 & 0.78 \\
\hline Mali & 2016 & 93 & 1.45 \\
\hline Morocco & 2013 & 177 & 2.77 \\
\hline Namibia & 2014 & 132 & 2.06 \\
\hline Senegal & 2014 & 242 & 3.78 \\
\hline Nigeria & 2014 & 1226 & 19.16 \\
\hline Niger & 2017 & 34 & 0.53 \\
\hline Total & & 6400 & 100 \\
\hline
\end{tabular}

Source: Authors' own computation based on WBES, 2018

years, has this establishment introduced any new or significantly improved process? Where process includes: methods of manufacturing products or offering services; logistics, delivery, or distribution methods for inputs, products, or services; or supporting activities for processes. (2) During the last 2 years, has this establishment introduced new or significantly improved products? The response to the two questions enabled us to categorise firms as those that undertook: (1) either product innovation or process innovation; (2) both process and product innovations; and (3) no innovation.

To ensure correctness of responses, questions regarding labour force characterization and sales emphasis were made to ensure that human resource managers and accountants were also interviewed respectively. ${ }^{7}$ Thus, firms responded to the questions regarding the number of permanent, full-time individuals they employed in the current year and 3 years ago which allowed us to measure employment growth. Therefore, the questions that this paper seeks to answer are: Is process and product innovations associated with cannibalism ${ }^{8}$ as regards employment growth? Is there complementarity between process and product innovations in how they relate with employment growth? Is 
the relationship between process and product innovations and employment growth uniform across firm sizes and age? Does innovation mitigate the effect of a weak business environment on employment growth?

The surveys targeted manufacturing and services sectors. This paper, however, focuses on the manufacturing sector.

\section{Variable description}

Employment growth (EG) is measured as the difference between permanent employees in the last fiscal year and 3 years before the survey divided by a firm's average permanent employees during the same period. This measure of employment growth follows Davis and Haltiwanger $(1992,1999)$ and Aterido et al. (2011) with the rationale that it allows for employment growth to be symmetric around zero with -2 as the lower bound and 2 as the upper bound. More specifically employment growth is measured.

$$
\mathrm{EG}_{\mathrm{ijc}}=\left(\mathrm{EG}_{\mathrm{ijct}}-\mathrm{EG}_{\mathrm{ijc}(t-3)}\right) /\left[\mathrm{EG}_{\mathrm{ijct}}+\mathrm{EG}_{\mathrm{ijc}(t-3)}\right] / 2
$$

where $t$ and $t-3$ index last fiscal year and 3 years before the survey, respectively. This method of measuring employment growth is argued to be monotonically related to the conventional measure of employment growth. Besides, it controls for employment growth outliers that would have been associated with firms experiencing for instance sharp contractions and expansions (Aterido et al. 2011).

Innovation is captured by process innovation and product innovation. Process innovation (Process) takes on values of ' 1 ' and ' 0 ' if a firm undertook process innovation and no process innovation, respectively. Product innovation (Product) takes on values of ' 1 ' and ' 0 ' if a firm undertook product innovation and no product innovation, respectively.

We also attempt to measure the possibility of complementarity between process and product innovations, hence the categorical variable Innov. Innov takes on a value of ' 0 ', ' 1 ' and ' 2 ' if a firm undertook no innovation, either product innovation or process innovation and both process and product innovations, respectively.

Note that relationship between process innovation and employment growth involves process innovation inducing productivity gains, thereby, reducing the unit cost of production (Griffith et al. 2006; Lööf and Heshmati 2006; and Van Leeuwen and Klomp 2006). The reduction in the unit cost of production results in price reduction. Price reduction is expected to induce an increase in demand and thus the sales of the product. The increased sales may result in an increase in productive capacity thus employment growth (Harrison et al. 2014). While for product innovation, new products may either increase or reduce the market share of the firm's old product(s). The net increases in sales, and therefore, employment growth depends on whether new products induce growth in the market share of the firm's products or not. Increased market share would induce increase in a firm's capacity which comes with employment growth. Unfortunately, WBES dataset does not distinguish between sales from new products and those from old products. Even then, sales growth (SalesG) is defined as the difference between a firm's sales in the last fiscal year and sales three fiscal years ago divided by three. ${ }^{9}$ 
We also measure business environment characteristics because they are complimentary to firm decisions. Specifically, we include Electricity, Bureaucracy, Bribe, Retained and Competition. With regard to source of financing, we use retained earnings, Retained. Retained is defined as the percentage of working capital financed by internal funds. Electricity is a proxy for the quality of public infrastructure. In this regard, Electricity takes on the value ' 1 ' if a firm experienced power outages in the last fiscal year otherwise ' 0 '.

Bureaucracy is a proxy for red tape. Bureaucracy is measured as the percentage of senior management time spent dealing with government officials. Bribe is captures informal payments made by firms to public officials in order to get 'things' done. Bribe is measured as the percentage of total annual sales paid in informal payment by a firm. Competition proxies competition from informal firms. Competition takes on a value of ' 1 ' if a firm experiences competition from informal firms otherwise ' 0 '.

Other variables of interest especially firm specific are described below. With regard to the nature of ownership, it is categorised as Government, Domestic and Foreign. Government takes a value of ' 1 ' if at least $10 \%$ of the firm is government owned otherwise ' 0 '. Foreign takes a value of ' 1 ' if at least $10 \%$ of the firm is foreign owned otherwise ' 0 '. Domestic takes a value of ' 1 ' if at least $10 \%$ of the firm is domestically owned otherwise ' 0 '. Managerial Experience (Mexperience) measures the manager's years of experience. The average years of experience of a manager is 18 years. In order to take care of large values, we take logs of Managerial Experience (InMexperience). In terms of location, it is represented by the variable Millioncity which takes on a value of ' 1 ' if the firm is located in a city with more than a million people otherwise ' 0 '. Finally, exporting takes on a value of ' 1 ' if the share of a firm's national sales are less than $100 \%$ otherwise ' 0 '. In essence, a firm is deemed to be exporting if some of its sales are sold beyond its national boundaries.

\section{Results and discussion}

\section{Descriptive statistics}

Table 1 presents the number of firms surveyed for each country by year of survey. In addition, across countries and irrespective of year of survey, manufacturing firms of interest are further categorized using the two-digit ISIC classification levels (Table 2).

More specifically, with respective to firm size, small firms employ between 5 and 20 employees. These constitute $47 \%$ of firms (Table 3). At 78\%, Nigeria has the highest proportion of small firms followed by Guinea, Djibouti and Tanzania, all at $71 \%$. Medium scale firms employ more than 20 employees but less than 99 employees and constitute $32 \%$ of the entire sample (Table 3). At 73\%, Burundi has the highest proportion of medium firms followed by Niger, Morocco, Mali and Tunisia at about $45 \%$ on average with Namibia (13\%) and Ivory Coast (17\%) having the smallest proportion of medium firms. Large firms employ over 100 employees and constitute $21 \%$ of the entire sample (Table 3). Lesotho (32\%) and Malawi (30\%) have the highest proportion of large firms. Both Djibouti and Niger did not have large firms in the sample.

With regard to age, firms are categorized as young, mature and older. Young firms are those that have been in existence for less than 5 years; mature firms have been in existence for between 6 and 15 years while older firms have been in existence for at least 16 years and above. From Table 3, 7\%, 37\% and 55\% of firms are young, mature and older firms, respectively. Across the entire sample, the average age of firms is 20 
Table 2 Manufacturing firms by ISIC

\begin{tabular}{|c|c|c|c|}
\hline ISIC & Industry name & Frequency & Percent \\
\hline 15 & Manufacture of leather and related products & 1733 & 27.08 \\
\hline 16 & $\begin{array}{l}\text { Manufacture of wood and of products of wood and cork, except } \\
\text { furniture; manufacture of articles of straw and plaiting material }\end{array}$ & 15 & 0.23 \\
\hline 17 & Manufacture of paper and paper products & 312 & 4.88 \\
\hline 18 & Printing and reproduction of recorded media & 705 & 11.02 \\
\hline 19 & Manufacture of coke and refined petroleum products & 192 & 3 \\
\hline 20 & Manufacture of chemicals and chemical products & 282 & 4.41 \\
\hline 21 & $\begin{array}{l}\text { Manufacture of basic pharmaceutical products and pharmaceutical } \\
\text { preparations }\end{array}$ & 98 & 1.53 \\
\hline 22 & Manufacture of rubber and plastics products & 521 & 8.14 \\
\hline 23 & Manufacture of other non-metallic mineral products & 37 & 0.58 \\
\hline 24 & Manufacture of basic metals & 427 & 6.67 \\
\hline 25 & $\begin{array}{l}\text { Manufacture of fabricated metal products, except machinery } \\
\text { and equipment }\end{array}$ & 370 & 5.78 \\
\hline 26 & Manufacture of computer, electronic and optical products & 595 & 9.3 \\
\hline 27 & Manufacture of electrical equipment & 161 & 2.52 \\
\hline 28 & Manufacture of machinery and equipment n.e.c. & 625 & 9.77 \\
\hline 29 & Manufacture of motor vehicles, trailers and semi-trailers & 171 & 2.67 \\
\hline 30 & Manufacture of other transport equipment & 3 & 0.05 \\
\hline 31 & Manufacture of furniture & 120 & 1.88 \\
\hline 32 & Other manufacturing & 11 & 0.17 \\
\hline \multirow[t]{2}{*}{33} & Manufacture of leather and related products & 22 & 0.34 \\
\hline & Total & 6400 & 100 \\
\hline
\end{tabular}

Source: Authors' own computation based on WBES, 2018

years. Namibia, CAR, Rwanda and DRC have the highest proportion of young firms at $40 \%, 38 \%, 32 \%$ and $30 \%$, respectively. Lesotho has the lowest proportion of young firms at $1 \%$ followed by Kenya, Malawi and Swaziland at $2 \%$ on average. With regard to mature firms, Lesotho and Uganda have the highest proportion of mature firms at $61 \%$ followed by Tanzania at $54 \%$. While at $21 \%, 25 \%$ and 26\%, Kenya, Egypt and Burundi have the lowest proportion of mature firms, respectively. With regard to older firms, Rwanda, Namibia and CAR have the lowest older firms.

From Table 3, the mean employment growth rate is 0.106 . Guinea, Tanzania and Rwanda have the highest employment growth level at $0.31,0.17$ and 0.24 , respectively. While at $-0.11,-0.03$ and -0.003 , Lesotho, Egypt and Niger have the lowest employment growth, respectively.

About 50.4\% of firms undertook process innovation (Table 3). Rwanda, Kenya and Uganda hand the highest proportion of firms that undertook process innovation at 87\%, 83\% and 81\%, respectively. While Egypt, Lesotho and Cameroon had the lowest proportion of firms that undertook process innovation at $4 \%, 5 \%$ and $10 \%$, respectively. Furthermore, $43 \%$ of firms were engaged in product innovation (Table 3). At $74 \%, 68 \%$ and 68\%, Uganda, Kenya and Namibia had the highest proportion of firms that undertook product innovation, respectively. In addition, $35.4 \%$ of firms were engaged in both product and process innovation. Furthermore, $21.3 \%$ of firms undertook either product or process innovation. Finally, $43.3 \%$ of firms undertook no innovation. 
Table 3 Descriptive summary statistics

\begin{tabular}{|c|c|c|c|c|c|}
\hline Variable & No. of observations & Mean & Std. Dev. & Min & Max \\
\hline Employment growth & 6400 & 0.11 & 0.45 & -2 & 2 \\
\hline \multicolumn{6}{|l|}{ Innov (0 = no innovation) } \\
\hline 1 (= Process/Product) & 6400 & 0.21 & 0.41 & 0 & 1 \\
\hline 2 (=Process $\times$ Product) & 6400 & 0.35 & 0.48 & 0 & 1 \\
\hline Product (1 = yes) & 6351 & 0.43 & 0.49 & 0 & 1 \\
\hline Process ( 1 = yes) & 6303 & 0.50 & 0.50 & 0 & 1 \\
\hline SalesG & 6262 & 0.10 & 0.79 & -4.37 & 7 \\
\hline Productivity & 6336 & $207,645.40$ & $7,786,660.00$ & 1.10265 & $6.06 \mathrm{E}+08$ \\
\hline R\&D (1 = yes) & 6326 & 0.21 & 0.41 & 0 & 1 \\
\hline Retained ( 1 = yes) & 6393 & 0.73 & 0.33 & 0 & 1 \\
\hline Small (1 = yes) & 6400 & 0.47 & 0.50 & 0 & 1 \\
\hline Medium (1 = yes) & 6400 & 0.32 & 0.47 & 0 & 1 \\
\hline Large (1 = yes) & 6400 & 0.21 & 0.41 & 0 & 1 \\
\hline Age & 6164 & 19.96 & 15.58 & 0 & 212 \\
\hline Young (1 = yes) & 6208 & 0.07 & 0.26 & 0 & 1 \\
\hline Older (1 = yes) & 6162 & 0.55 & 0.50 & 0 & 1 \\
\hline Mature (1 = yes) & 6400 & 0.37 & 0.48 & 0 & 1 \\
\hline Mexperience & 6202 & 17.90 & 11.12 & 1 & 72 \\
\hline Domestic & 6372 & 0.88 & 0.32 & 0 & 1 \\
\hline Foreign (1 = yes) & 6355 & 0.17 & 0.38 & 0 & 1 \\
\hline Government (1 = yes) & 6360 & 0.05 & 0.23 & 0 & 1 \\
\hline Millioncity (1 = yes) & 6400 & 0.36 & 0.48 & 0 & 1 \\
\hline Exporting ( 1 = yes) & 6400 & 0.28 & 0.45 & 0 & 1 \\
\hline Electricity ( 1 = yes) & 6350 & 0.70 & 0.46 & 0 & 1 \\
\hline Bureaucracy & 6359 & 10.26 & 21.34 & 0 & 100 \\
\hline Bribe & 6298 & 1.46 & 6.73 & 0 & 100 \\
\hline Competition ( $1=$ yes) & 5995 & 0.57 & 0.50 & 0 & 1 \\
\hline
\end{tabular}

Source: Authors' own computation based on WBES, 2018

Firms in Uganda (27\%), Tanzania (24\%), Ivory Coast (6\%) and Kenya (2\%) have negative sales growth, respectively. While those in Sudan (94\%), Nigeria (23\%) and Guinea (19\%) have the highest sales growth. Across the entire sample, the average sales growth is $10 \%$. Productivity (Prod) is defined as the ratio of sales in the last fiscal year divided by the current year employment. Overall, the mean labour productivity in the sample is US $\$ 206,967$. About $73 \%$ of working capital used by firms is financed by internal funds. Retained captures the extent of exclusion from the credit market.

On average, $70 \%$ of firms reported to have experienced electricity outages with the highest cases reported in Niger, Burundi, Ghana and Sudan at about $92 \%$ on average. Firms in Tunisia, Namibia, Morocco and Egypt reported to have least experienced electricity outages. With regard to bureaucracy, on average, $10.3 \%$ of senior management time was spent dealing with government officials. More bureaucracies were found in Tunisia (45\%) and Niger (19\%) while Swaziland, Djibouti, Sudan and Tanzania had the least time in which senior managers of firms spent negotiating with public officials, respectively. 
About 1.5\% of total annual sales are lost as informal payments (bribes) to public officials especially by firms in Niger, Mali Cameroon and CAR while those in Rwanda, Morocco and Senegal paid the least bribes. From Table 3, 57\% of firms experience competition from informal firms. Furthermore, about $17 \%, 88.4 \%$ and $5.5 \%$ of firms are foreign, domestic and government owned, respectively. In addition, on average, $28 \%$ of firms engage in exporting part of their total sales.

\section{Empirical model estimates and analysis}

Equations 3.1 to 3.4 are estimated using the pooled OLS with results in Tables 4, 5, 6 and 7, respectively. Note the likelihood of endogeneity since employment growth can result from a firm hiring new workers who engage in R\&D, the effect of which can be new innovations. Or the newly hired workers can be for purposes of managing the implementation of the new innovations. Hence, instrumental variable estimates for 2SLS are presented in Table 8.

Employment growth is positively associated with product innovation (Table 4models 3, 6 and 9). Results are consistent with findings by Peters (2004), Benavente and Lauterbach (2008), Bogliacino et al. (2012), Greenan and Guellec (2000), Lachenmaier and Rottmann (2011), Evangelista and Vezzani (2012), Harrison et al. (2014), Elejalde et al. (2015) and Aboal et al. (2015). The positive relationship between product innovation and employment is attributed to the increase in sales and thus firm market share following the introduction of a new product (Harrison et al. 2014). Nonetheless, due to data constraints, the relationship between product innovation and sales growth from the new products was not undertaken.

Furthermore, employment growth is positively associated with process innovation (Table 4-model 5). This result is consistent with Greenan and Guellec (2000), Lachenmaier and Rottmann (2011), Harrison et al. (2014), Cirera and Sabetti (2016) and Fukao et al. (2017) who show that employment growth is positively associated with process innovation. The link between process innovation and employment growth is through unit cost reductions associated with efficiency gains attributed to process innovation. The reduction in unit costs results in price reduction hence an increase in firm sales. The increase in firm sales induces capacity enhancement implying employment growth. Despite the lack of data on prices of firm products following process innovations to allow for a structural analysis from process innovation to employment growth, even then, Table 9-models 2 and 5-shows that productivity is positively associated with process innovation. ${ }^{10}$ The positive relationship between productivity and process innovation is partly because process innovation results in efficiency gains which induce price reductions leading to higher sales. Indeed, from Table 10 (models 2 and 5) sales growth is positively associated with both productivity and process innovation. Higher sales induce incentives for capacity growth implying employment growth.

Moreover, product and process innovations are associated with complementarity effects in their relationship with employment growth. Firms that engage in both process and product innovation are associated with positive employment growth compared to non-innovating firms (Table 4-models 1 and 4). Evangelista and Vezzani (2012) also found similar results in which employment growth was strongest among firms that engaged in process, organisational and product innovations. ${ }^{11}$ The complementarity perhaps suggests that it is not enough to introduce new products, rather they ought to be 
Table 4 Baseline model, employment growth and innovation

\begin{tabular}{|c|c|c|c|c|c|c|}
\hline & (1) & $(2)$ & (3) & (4) & (5) & (6) \\
\hline & $\begin{array}{l}\text { Employment } \\
\text { growth }\end{array}$ & $\begin{array}{l}\text { Employment } \\
\text { growth }\end{array}$ & $\begin{array}{l}\text { Employment } \\
\text { growth }\end{array}$ & $\begin{array}{l}\text { Employment } \\
\text { growth }\end{array}$ & $\begin{array}{l}\text { Employment } \\
\text { growth }\end{array}$ & $\begin{array}{l}\text { Employment } \\
\text { growth }\end{array}$ \\
\hline \multicolumn{7}{|c|}{ Innov $(0=$ no innovation $)$} \\
\hline \multirow[t]{2}{*}{$(=$ Process/Product) } & -0.006 & & & 0.0001 & & \\
\hline & $(0.0160)$ & & & $(0.0168)$ & & \\
\hline \multirow{2}{*}{$\begin{array}{l}2 \text { (= Process } \times \\
\text { Product) }\end{array}$} & $0.04^{*}$ & & & $0.06^{* * *}$ & & \\
\hline & $(0.0156)$ & & & $(0.0166)$ & & \\
\hline \multirow[t]{2}{*}{ Process ( 1 = yes) } & & 0.01 & & & $0.03^{*}$ & \\
\hline & & $(0.0140)$ & & & (0.0148) & \\
\hline \multirow[t]{2}{*}{ Product (1 = yes) } & & & $0.04^{* * *}$ & & & $0.05^{* * *}$ \\
\hline & & & $(0.0125)$ & & & $(0.0132)$ \\
\hline \multirow[t]{2}{*}{ SalesG } & $0.04^{* * *}$ & $0.04^{* * *}$ & $0.04^{* * *}$ & $0.04^{* * *}$ & $0.04^{* * *}$ & $0.04^{* * *}$ \\
\hline & $(0.0106)$ & $(0.0108)$ & $(0.0107)$ & $(0.0114)$ & $(0.0115)$ & $(0.0114)$ \\
\hline \multirow[t]{2}{*}{ Productivity } & $-0.03^{* * *}$ & $-0.03^{* * *}$ & $-0.03^{* * *}$ & $-0.03^{* * *}$ & $-0.03^{* * *}$ & $-0.03^{* * *}$ \\
\hline & $(0.00439)$ & $(0.00440)$ & $(0.00438)$ & $(0.00455)$ & $(0.00456)$ & $(0.00453)$ \\
\hline \multirow[t]{2}{*}{ Retained } & 0.002 & 0.002 & 0.001 & 0.004 & 0.006 & 0.003 \\
\hline & $(0.0192)$ & $(0.0194)$ & $(0.0192)$ & $(0.0200)$ & $(0.0202)$ & $(0.0200)$ \\
\hline \multicolumn{7}{|l|}{ Size } \\
\hline \multirow[t]{2}{*}{ Medium } & $0.09^{* * *}$ & $0.09^{* * *}$ & $0.09^{* * *}$ & $0.08^{* * *}$ & $0.09^{* * *}$ & $0.08^{* * *}$ \\
\hline & $(0.0145)$ & $(0.0147)$ & $(0.0145)$ & $(0.0151)$ & $(0.0152)$ & $(0.0151)$ \\
\hline \multirow[t]{2}{*}{ Large } & $0.1^{* * *}$ & $0.1^{* * *}$ & $0.1^{* * *}$ & $0.1^{* * *}$ & $0.1^{* * *}$ & $0.1^{* * *}$ \\
\hline & $(0.0194)$ & (0.0195) & (0.0195) & $(0.0202)$ & $(0.0202)$ & $(0.0202)$ \\
\hline \multirow[t]{2}{*}{ InAge } & $-0.04^{* * *}$ & $-0.04^{* * *}$ & $-0.04^{* * *}$ & $-0.04^{* * *}$ & $-0.05^{* * *}$ & $-0.05^{* * *}$ \\
\hline & $(0.00881)$ & $(0.00882)$ & $(0.00877)$ & $(0.00910)$ & $(0.00910)$ & $(0.00905)$ \\
\hline \multirow[t]{2}{*}{ InMexperience } & 0.009 & 0.007 & 0.009 & 0.009 & 0.007 & 0.009 \\
\hline & $(0.00935)$ & $(0.00922)$ & $(0.00913)$ & $(0.00980)$ & $(0.00965)$ & $(0.00955)$ \\
\hline \multirow[t]{2}{*}{ Foreign ( 1 = yes) } & 0.002 & -0.0004 & 0.001 & -0.005 & -0.009 & -0.005 \\
\hline & $(0.0162)$ & $(0.0163)$ & $(0.0161)$ & $(0.0170)$ & $(0.0170)$ & $(0.0169)$ \\
\hline \multirow[t]{2}{*}{ Government ( 1 = yes) } & 0.06 & 0.06 & $0.07^{+}$ & $0.07^{+}$ & $0.07^{+}$ & $0.08^{*}$ \\
\hline & $(0.0386)$ & $(0.0393)$ & $(0.0380)$ & $(0.0403)$ & $(0.0408)$ & $(0.0395)$ \\
\hline \multirow[t]{2}{*}{ Millioncity (1 = yes) } & -0.005 & -0.005 & -0.006 & -0.01 & -0.01 & -0.01 \\
\hline & $(0.0133)$ & $(0.0134)$ & $(0.0133)$ & $(0.0137)$ & $(0.0137)$ & $(0.0136)$ \\
\hline \multirow[t]{2}{*}{ Exporting ( $1=$ yes) } & -0.008 & -0.005 & -0.009 & -0.02 & -0.01 & -0.02 \\
\hline & $(0.0150)$ & $(0.0151)$ & $(0.0150)$ & $(0.0156)$ & $(0.0157)$ & $(0.0156)$ \\
\hline \multirow[t]{2}{*}{ Electricity ( 1 = yes) } & & & & $-0.03^{+}$ & -0.02 & $-0.03^{+}$ \\
\hline & & & & $(0.0155)$ & $(0.0154)$ & $(0.0154)$ \\
\hline \multirow[t]{2}{*}{ Bureaucracy } & & & & $-0.0006^{*}$ & $-0.0006^{*}$ & $-0.0006^{*}$ \\
\hline & & & & $(0.000277)$ & $(0.000278)$ & $(0.000276)$ \\
\hline \multirow[t]{2}{*}{ Bribe } & & & & 0.0008 & 0.0007 & 0.0007 \\
\hline & & & & $(0.000974)$ & $(0.000972)$ & $(0.000963)$ \\
\hline \multicolumn{2}{|l|}{ Competition ( 1 = yes) } & & & -0.01 & -0.01 & -0.01 \\
\hline Country fixed effects & Yes & Yes & Yes & Yes & Yes & Yes \\
\hline \multirow[t]{2}{*}{ ISIC fixed effects } & Yes & Yes & Yes & Yes & Yes & Yes \\
\hline & & & & $(0.0129)$ & $(0.0129)$ & $(0.0128)$ \\
\hline Constant & $0.4^{* * *}$ & $0.4^{* * *}$ & $0.4^{* * *}$ & $0.4^{* * *}$ & $0.4^{* * *}$ & $0.4^{* * *}$ \\
\hline
\end{tabular}


Table 4 Baseline model, employment growth and innovation (Continued)

\begin{tabular}{lllllll}
\hline & $(1)$ & $(2)$ & $(3)$ & $(4)$ & $(5)$ & $(6)$ \\
& $\begin{array}{l}\text { Employment } \\
\text { growth }\end{array}$ & $\begin{array}{l}\text { Employment } \\
\text { growth }\end{array}$ & $\begin{array}{l}\text { Employment } \\
\text { growth }\end{array}$ & $\begin{array}{l}\text { Employment } \\
\text { growth }\end{array}$ & $\begin{array}{l}\text { Employment } \\
\text { growth }\end{array}$ & $\begin{array}{l}\text { Employment } \\
\text { growth }\end{array}$ \\
\hline & $(0.0511)$ & $(0.0512)$ & $(0.0507)$ & $(0.0549)$ & $(0.0551)$ & $(0.0547)$ \\
$N$ & 5822 & 5762 & 5798 & 5389 & 5337 & 5370 \\
$R^{2}$ & 0.062 & 0.060 & 0.062 & 0.066 & 0.063 & 0.067 \\
Adj. $R^{2}$ & 0.053 & 0.051 & 0.053 & 0.055 & 0.053 & 0.056 \\
\hline
\end{tabular}

Note: (1) All models are pooled OLS with standard errors adjusted for clusters using unique firm identifiers. (2) Standard errors in parentheses. (3) Significance levels: ${ }^{+} p<0.10,{ }^{*} p<0.05,{ }^{* * *} p<0.001$

Source: Authors' own computation based on WBES, 2018

complimented with an efficient organisational and logistical framework to ensure consistent supplies in terms of quality and quantity in the shortest time possible.

Also, the complementarity between process and product innovation in propagating employment growth is evident among young and older firms. Table 5 (model 1) shows that employment growth is increasing among older and young firms that engage in both process and product innovation compared to the non-innovators. This suggests that irrespective of a firm's age, employment growth is likely to increase among firms that engage in any form of innovation.

Furthermore, employment growth is negatively associated with small firms but positively in large firms (Table 4-models 4, 5, 6, 7, 8 and 9). Such findings suggest that employment growth in Africa is more likely among large firms compared to small firms. Since firm size is measured by the number of workers a firm employs, then results can also simply suggest that firms may not have an incentive to upgrade from their initial size. This shows limitations in transitions among firms.

Note that across all models, employment growth is positively associated with medium and large firms compared to small firms (Table 4). An attempt is further made to understand whether the relationship between innovation and employment growth is conditioned on firm size. From Table 6, results from model 1 after interacting innovation and firm size show that employment growth is positively associated with innovation among firms that engage in both process and product innovation compared to firms that do not engage in innovation. The relationship is strongest among large firms and neutral among small firms. In addition, employment growth is directly related to innovation among firms that choose either product or process innovation compared to firms that do not engage in innovation especially among large firms.

Furthermore, interactions between process innovation and large firms indicate that the relationship between process innovation and employment growth is positive and significant (Table 6-model 2). The result suggests the relationship between innovations especially process innovation, and employment growth is conditioned on firm size. Indeed, Meriküll (2010) also find similar findings among medium firms in Estonia. Furthermore, Table 6 (model 3) shows that the positive relationship between employment growth and product innovation is not conditioned on large or small firms in Africa. This is contrary to Peters (2004) who argues that employment growth is positively associated with product innovation among larger firms in Germany.

In light of firm age, across all models in Table 4, employment growth is inversely related with firm age, suggesting that the older a firm is, the lower the likelihood of 
Table $\mathbf{5}$ Interaction between innovation and firm age

\begin{tabular}{|c|c|c|c|}
\hline & (1) & (2) & (3) \\
\hline & Employment growth & Employment growth & Employment growth \\
\hline \multicolumn{4}{|l|}{ Innov (0 = no innovation) } \\
\hline \multirow[t]{2}{*}{1 (= Process/Product) } & -0.03 & & \\
\hline & $(0.0267)$ & & \\
\hline \multirow[t]{2}{*}{$2(=$ Process $\times$ Product $)$} & 0.001 & & \\
\hline & $(0.0247)$ & & \\
\hline \multirow[t]{2}{*}{ Process ( 1 = yes) } & & -0.02 & \\
\hline & & $(0.0218)$ & \\
\hline \multirow[t]{2}{*}{ Product (1 = yes) } & & & 0.02 \\
\hline & & & $(0.0209)$ \\
\hline \multirow[t]{2}{*}{ Young (1 = yes) } & -0.02 & -0.01 & 0.002 \\
\hline & $(0.0412)$ & $(0.0386)$ & $(0.0351)$ \\
\hline \multirow[t]{2}{*}{ Older (1 = yes) } & $-0.10^{* * *}$ & $-0.09 * * *$ & $-0.08^{* * *}$ \\
\hline & $(0.0202)$ & $(0.0189)$ & $(0.0176)$ \\
\hline \multicolumn{4}{|l|}{ Innovation $\times$ Young } \\
\hline \multirow[t]{2}{*}{1} & 0.03 & & \\
\hline & $(0.0647)$ & & \\
\hline \multirow[t]{2}{*}{2} & $0.1^{+}$ & & \\
\hline & $(0.0593)$ & & \\
\hline \multicolumn{4}{|l|}{ Innovation $\times$ Older } \\
\hline \multirow[t]{2}{*}{1} & 0.05 & & \\
\hline & $(0.0330)$ & & \\
\hline \multirow[t]{2}{*}{2} & $0.07^{*}$ & & \\
\hline & $(0.0296)$ & & \\
\hline \multirow[t]{2}{*}{ Process $\times$ Young } & & 0.08 & \\
\hline & & $(0.0519)$ & \\
\hline \multirow[t]{2}{*}{ Process $\times$ Older } & & $0.07^{* *}$ & \\
\hline & & $(0.0259)$ & \\
\hline \multirow[t]{2}{*}{ Product $\times$ Young } & & & 0.07 \\
\hline & & & $(0.0521)$ \\
\hline \multirow[t]{2}{*}{ Product $\times$ Older } & & & $0.05^{+}$ \\
\hline & & & $(0.0259)$ \\
\hline Country fixed effects & Yes & Yes & Yes \\
\hline ISIC fixed effects & Yes & Yes & Yes \\
\hline \multirow[t]{2}{*}{ Constant } & $0.5^{* * *}$ & $0.5^{* * *}$ & $0.5^{* * *}$ \\
\hline & $(0.0587)$ & $(0.0589)$ & $(0.0585)$ \\
\hline N & 5168 & 5117 & 5146 \\
\hline$R^{2}$ & 0.072 & 0.069 & 0.071 \\
\hline Adj. $R^{2}$ & 0.060 & 0.057 & 0.060 \\
\hline
\end{tabular}

Note: (1) All models are pooled OLS with standard errors adjusted for clusters using unique firm identifiers. (2) Standard errors in parentheses. (3) Significance levels: ${ }^{+} p<0.10,{ }^{*} p<0.05,{ }^{* *} p<0.01,{ }^{* * *} p<0.001$. (3) All models control for firmspecific and business environment characteristics

Source: Authors' own computation based on WBES, 2018 
Table 6 Interaction between innovation and firm size

\begin{tabular}{|c|c|c|c|}
\hline & $(1)$ & $(2)$ & (3) \\
\hline & Employment growth & Employment growth & Employment growth \\
\hline \multicolumn{4}{|l|}{ Innov (0 = no innovation) } \\
\hline \multirow[t]{2}{*}{1 (= Process/Product) } & -0.03 & & \\
\hline & $(0.0260)$ & & \\
\hline \multirow[t]{2}{*}{2 (=Process $\times$ Product) } & $0.05^{*}$ & & \\
\hline & $(0.0247)$ & & \\
\hline \multirow[t]{2}{*}{ Process ( 1 = yes) } & & 0.02 & \\
\hline & & $(0.0219)$ & \\
\hline \multirow[t]{2}{*}{ Product (1 = yes) } & & & $0.06^{* *}$ \\
\hline & & & $(0.0211)$ \\
\hline \multirow[t]{2}{*}{ Small (1 = yes) } & $-0.08^{* * *}$ & $-0.08^{* * *}$ & $-0.07^{* * *}$ \\
\hline & $(0.0211)$ & (0.0198) & $(0.0183)$ \\
\hline \multirow[t]{2}{*}{ Large (1 = yes) } & -0.02 & -0.008 & 0.02 \\
\hline & $(0.0230)$ & $(0.0215)$ & $(0.0214)$ \\
\hline \multicolumn{4}{|l|}{ Innovation × Large } \\
\hline \multirow[t]{2}{*}{1} & $0.1^{* *}$ & & \\
\hline & $(0.0400)$ & & \\
\hline \multirow[t]{2}{*}{2} & $0.09^{* *}$ & & \\
\hline & $(0.0348)$ & & \\
\hline \multicolumn{4}{|l|}{ Innovation $\times$ Small } \\
\hline \multirow[t]{2}{*}{1} & 0.01 & & \\
\hline & $(0.0337)$ & & \\
\hline \multirow[t]{2}{*}{2} & -0.03 & & \\
\hline & $(0.0312)$ & & \\
\hline \multirow[t]{2}{*}{ Process $\times$ Large } & & $0.10^{* *}$ & \\
\hline & & $(0.0311)$ & \\
\hline \multirow[t]{2}{*}{ Process $\times$ Small } & & -0.02 & \\
\hline & & $(0.0272)$ & \\
\hline \multirow[t]{2}{*}{ Product $\times$ Large } & & & 0.05 \\
\hline & & & $(0.0309)$ \\
\hline \multirow[t]{2}{*}{ Product $\times$ Small } & & & -0.04 \\
\hline & & & $(0.0274)$ \\
\hline Country fixed effects & Yes & Yes & Yes \\
\hline ISIC fixed effects & Yes & Yes & Yes \\
\hline \multirow[t]{2}{*}{ Constant } & $0.5^{* * *}$ & $0.5^{* * *}$ & $0.5^{* * *}$ \\
\hline & $(0.0586)$ & $(0.0590)$ & $(0.0582)$ \\
\hline N & 5389 & 5337 & 5370 \\
\hline$R^{2}$ & 0.069 & 0.066 & 0.068 \\
\hline Adj. $R^{2}$ & 0.057 & 0.055 & 0.057 \\
\hline
\end{tabular}

Note: (1) All models are pooled OLS with standard errors adjusted for clusters using unique firm identifiers. (2) Standard errors in parentheses. (3) Significance levels: ${ }^{*} p<0.05,{ }^{* *} p<0.01,{ }^{* * *} p<0.001$. (3) All models control for firm-specific and business environment characteristics

Source: Authors' own computation based on WBES, 2018 
Table $\mathbf{7}$ Interaction between innovation and the business environment

\begin{tabular}{|c|c|c|c|}
\hline & (1) & (2) & (3) \\
\hline & Employment growth & Employment growth & Employment growth \\
\hline \multicolumn{4}{|l|}{ Innov (0 = no innovation) } \\
\hline \multirow[t]{2}{*}{1 (= Process/Product) } & $0.07^{*}$ & & \\
\hline & $(0.0322)$ & & \\
\hline \multirow[t]{2}{*}{2 (= Process $\times$ Product $)$} & $0.1^{* *}$ & & \\
\hline & $(0.0371)$ & & \\
\hline \multirow[t]{2}{*}{ Process ( 1 = yes) } & & $0.10^{* *}$ & \\
\hline & & $(0.0304)$ & \\
\hline \multirow[t]{2}{*}{ Product (1 = yes) } & & & $0.09^{* *}$ \\
\hline & & & $(0.0314)$ \\
\hline \multirow[t]{2}{*}{ Electricity ( 1 = yes) } & 0.01 & 0.01 & -0.003 \\
\hline & $(0.0190)$ & $(0.0181)$ & $(0.0168)$ \\
\hline \multirow[t]{2}{*}{ Bureaucracy } & -0.0006 & -0.0006 & $-0.0007^{+}$ \\
\hline & $(0.000420)$ & $(0.000399)$ & $(0.000375)$ \\
\hline \multirow[t]{2}{*}{ Bribe } & 0.001 & 0.002 & 0.0005 \\
\hline & $(0.00142)$ & $(0.00144)$ & $(0.00131)$ \\
\hline \multirow[t]{2}{*}{ Competition } & -0.007 & -0.005 & -0.02 \\
\hline & $(0.0186)$ & $(0.0172)$ & $(0.0160)$ \\
\hline \multicolumn{4}{|l|}{ Innovation $\times$ Electricity } \\
\hline \multirow[t]{2}{*}{1} & $-0.09^{* *}$ & & \\
\hline & $(0.0340)$ & & \\
\hline \multirow[t]{2}{*}{2} & $-0.09^{* *}$ & & \\
\hline & $(0.0345)$ & & \\
\hline \multirow[t]{2}{*}{ Innovation $\times$ Bureaucracy } & 0.00010 & & \\
\hline & $(0.000312)$ & & \\
\hline \multirow[t]{2}{*}{ Innovation $\times$ Bribe } & -0.0005 & & \\
\hline & $(0.000989)$ & & \\
\hline \multicolumn{4}{|l|}{ Innovation $\times$ Competition } \\
\hline \multirow[t]{2}{*}{1} & -0.02 & & \\
\hline & $(0.0308)$ & & \\
\hline \multirow[t]{2}{*}{2} & -0.0007 & & \\
\hline & $(0.0285)$ & & \\
\hline \multirow[t]{2}{*}{ Process $\times$ Electricity } & & $-0.08^{* *}$ & \\
\hline & & $(0.0286)$ & \\
\hline \multirow[t]{2}{*}{ Process $\times$ Bureaucracy } & & 0.00008 & \\
\hline & & $(0.000525)$ & \\
\hline \multirow[t]{2}{*}{ Process $\times$ Bribe } & & -0.001 & \\
\hline & & $(0.00190)$ & \\
\hline \multirow[t]{2}{*}{ Process $\times$ Competition } & & -0.009 & \\
\hline & & $(0.0245)$ & \\
\hline \multirow[t]{2}{*}{ Product $\times$ Electricity } & & & $-0.07^{*}$ \\
\hline & & & $(0.0299)$ \\
\hline \multirow[t]{2}{*}{ Product $\times$ Bureaucracy } & & & 0.0003 \\
\hline & & & $(0.000531)$ \\
\hline
\end{tabular}


Table $\mathbf{7}$ Interaction between innovation and the business environment (Continued)

\begin{tabular}{llll}
\hline & $(1)$ & $(2)$ & $(3)$ \\
& Employment growth & Employment growth & Employment growth \\
\hline Product $\times$ Bribe & & & 0.0004 \\
& & & $(0.00189)$ \\
Product $\times$ Competition & & & 0.02 \\
& & & $(0.0248)$ \\
Country fixed effects & Yes & Yes & Yes \\
ISIC & Yes & Yes & Yes \\
Constant & $0.4^{* * *}$ & $0.4^{* * *}$ & $0.4^{* * *}$ \\
& $(0.0570)$ & $(0.0567)$ & $(0.0558)$ \\
$N$ & 5389 & 5337 & 5370 \\
$R^{2}$ & 0.068 & 0.065 & 0.068 \\
Adj. $R^{2}$ & 0.056 & 0.054 & 0.057 \\
\hline
\end{tabular}

Note: (1) All models are pooled OLS with standard errors adjusted for clusters using unique firm identifiers. (2) Standard errors in parentheses. (3) Significance levels: ${ }^{+} p<0.10,{ }^{*} p<0.05,{ }^{* *} p<0.01,{ }^{* *} p<0.001$. (4) All models control for firm-specific characteristics

Source: Authors' own computation based on WBES, 2018

employment growth. However, interacting firm age and innovation shows that the relationship between innovation and employment growth is not conditioned on firm age. Specifically, Table 5 (model 2) reveals that employment growth is positively associated with process innovation among older firms. This implies that process innovation improves efficiency among older firms resulting in lower costs of production which also result in price reduction hence increased demand for the firm's product(s). This, in turn, induces capacity enhancement which further result in employment growth. Also, employment growth is directly related with product innovation among older firms. Similarly, employment growth is shown to be positively associated with older and younger firms that engage in both process and product innovation (Table 5-model 1). Hence, the relationship between innovation and employment growth is not conditioned on firm age.

With regard to the business environment, employment growth is undermined among firms that experience electricity outages compared to those that do not (Table 4models 4 and 6). Since electricity outages represent the quality of public infrastructure, this suggests that poor public infrastructure undermines employment growth. Electricity outages are associated with production inefficiencies as a result of idleness during blackouts. This can ultimately lead to laying off workers especially if the shortages negatively affect firm sales and thus profits. Also, employment growth is inversely related to bureaucratic rigidities (Table 4-models 4, 5 and 6). Since bureaucratic rigidities proxy the quality of institutional framework, results thus suggest that a weak institutional framework undermines employment growth. Note that red tape results in misallocation of production time among managers. As opposed to thinking about the strategic direction of a firm, managers are bogged down in non-productive meetings with public officials which undermine firm productivity and profitability potentially constraining employment growth. Therefore, consistent with Aterido and Hallward-Driermeier (2010), results herein indicate that employment growth is inversely related with a weak business environment. 
Table 8 Instrumental variables (2SLS) regressions

\begin{tabular}{|c|c|c|c|c|}
\hline & (1) & $(2)$ & (3) & (4) \\
\hline & Employment growth & Employment growth & Employment growth & Employment growth \\
\hline \multirow[t]{2}{*}{ Process ( 1 = yes) } & 0.03 & & -0.0001 & \\
\hline & $(0.0627)$ & & $(0.0659)$ & \\
\hline \multirow[t]{2}{*}{ Product ( 1 = yes) } & & 0.03 & & 0.002 \\
\hline & & $(0.0574)$ & & $(0.0601)$ \\
\hline \multirow[t]{2}{*}{ SalesG } & $0.04^{* * *}$ & $0.04^{* * *}$ & $0.04^{* * *}$ & $0.04^{* * *}$ \\
\hline & $(0.0107)$ & $(0.0106)$ & $(0.0114)$ & $(0.0113)$ \\
\hline \multirow[t]{2}{*}{ Productivity } & $-0.03^{* * *}$ & $-0.03^{* * *}$ & $-0.03^{* * *}$ & $-0.03^{* * *}$ \\
\hline & $(0.00453)$ & $(0.00449)$ & $(0.00475)$ & $(0.00468)$ \\
\hline \multirow[t]{2}{*}{ Retained } & 0.003 & 0.0005 & 0.004 & 0.001 \\
\hline & (0.0196) & $(0.0192)$ & $(0.0202)$ & $(0.0200)$ \\
\hline \multicolumn{5}{|l|}{ Size (small) } \\
\hline \multirow[t]{2}{*}{ Medium } & $0.09^{* * *}$ & $0.09^{* * *}$ & $0.09^{* * *}$ & $0.08^{* * *}$ \\
\hline & $(0.0153)$ & $(0.0150)$ & $(0.0160)$ & $(0.0156)$ \\
\hline \multirow[t]{2}{*}{ Large } & $0.1^{* * *}$ & $0.1^{* * *}$ & $0.1^{* * *}$ & $0.1^{* * *}$ \\
\hline & $(0.0205)$ & $(0.0204)$ & $(0.0214)$ & $(0.0210)$ \\
\hline \multirow[t]{2}{*}{ InAge } & $-0.04^{* * *}$ & $-0.04^{* * *}$ & $-0.05^{* * *}$ & $-0.05^{* * *}$ \\
\hline & $(0.00880)$ & $(0.00877)$ & $(0.00908)$ & $(0.00906)$ \\
\hline \multirow[t]{2}{*}{ InMexperience } & 0.007 & 0.008 & 0.007 & 0.008 \\
\hline & $(0.00918)$ & $(0.00911)$ & $(0.00961)$ & $(0.00954)$ \\
\hline \multirow[t]{2}{*}{ Foreign (1 = yes) } & -0.001 & -0.001 & -0.008 & -0.008 \\
\hline & $(0.0162)$ & $(0.0161)$ & $(0.0170)$ & $(0.0169)$ \\
\hline \multirow[t]{2}{*}{ Government ( $1=$ yes) } & 0.06 & $0.07^{+}$ & $0.07^{+}$ & $0.07^{+}$ \\
\hline & $(0.0383)$ & $(0.0380)$ & $(0.0397)$ & $(0.0395)$ \\
\hline \multirow[t]{2}{*}{ Millioncity (1 = yes) } & -0.006 & -0.005 & -0.01 & -0.01 \\
\hline & (0.0133) & $(0.0132)$ & $(0.0137)$ & $(0.0137)$ \\
\hline \multirow[t]{2}{*}{ Exporting ( $1=$ yes $)$} & -0.005 & -0.004 & -0.009 & -0.009 \\
\hline & $(0.0160)$ & $(0.0160)$ & $(0.0166)$ & $(0.0167)$ \\
\hline \multirow[t]{2}{*}{ Electricity ( 1 = yes) } & & & -0.02 & -0.02 \\
\hline & & & $(0.0162)$ & $(0.0164)$ \\
\hline \multirow[t]{2}{*}{ Bureaucracy } & & & $-0.0006^{*}$ & $-0.0005^{*}$ \\
\hline & & & $(0.000287)$ & $(0.000280)$ \\
\hline \multirow[t]{2}{*}{ Bribe } & & & 0.0007 & 0.0007 \\
\hline & & & $(0.000959)$ & $(0.000956)$ \\
\hline \multirow[t]{2}{*}{ Competition } & & & -0.008 & -0.010 \\
\hline & & & $(0.0137)$ & $(0.0141)$ \\
\hline Country fixed effects & Yes & Yes & Yes & Yes \\
\hline ISIC fixed effects & Yes & Yes & Yes & Yes \\
\hline \multirow[t]{2}{*}{ Constant } & $0.4^{* * *}$ & $0.4^{* * *}$ & $0.4^{* * *}$ & $0.5^{* * *}$ \\
\hline & (0.0538) & $(0.0520)$ & $(0.0555)$ & $(0.0549)$ \\
\hline N & 5735 & 5764 & 5313 & 5342 \\
\hline
\end{tabular}


Table 8 Instrumental variables (2SLS) regressions (Continued)

\begin{tabular}{lllll}
\hline & $(1)$ & $(2)$ & $(3)$ & $(4)$ \\
& Employment growth & Employment growth & Employment growth & Employment growth \\
\hline$R^{2}$ & 0.059 & 0.061 & 0.062 & 0.063 \\
Adj. $R^{2}$ & 0.050 & 0.052 & 0.051 & 0.052 \\
Prob $>$ F (First stage) & 0.0000 & 0.0000 & 0.0000 & 0.0000 \\
Durbin (score) chi(2) & 0.8313 & 0.7520 & 0.6591 & 0.4036 \\
Wu-Hausman & 0.8322 & 0.7532 & 0.6610 & 0.4064 \\
\hline
\end{tabular}

Note: (1) All models are estimated with standard errors adjusted for clusters using unique firm identifiers. (2) Standard errors in parentheses. (3) Significance levels: ${ }^{+} p<0.10,{ }^{*} p<0.05,{ }^{* * *} p<0.001$

Source: Authors' own computation based on WBES, 2018

With regard to whether the relationship between innovation and employment growth is conditioned on the quality of business environment, results in Table 7 (models 2 and 3 ) indicate that employment growth is positively associated with both process and product innovations. However, employment growth is inversely related to process and product innovation among firms that experience electricity outages compared to firms that do not experience electricity outages. This result suggests that the positive association between innovation and employment growth is conditioned on the availability of consistent electricity supply. Simply put, results therefore suggest that if the positive relationship between innovation and employment growth is to be optimized, the quality and quantity of public infrastructure should be good.

\section{Conclusion and policy implications}

Using the WBES dataset of manufacturing firms from 27 African countries, this paper set out to understand whether (1) there is positive, negative or neutral relationship between employment growth and innovation, (2) there is complementarity between process and product innovation in how they relate with employment growth, (3) the relationship between innovation and employment growth is uniform irrespective of firm size and age and (4) the relationship between innovation and employment growth is conditioned on the quality of the business environment.

Results indicate that employment growth is positively associated with both process and product innovations. Moreover, process and product innovation complement each other in their relationship with employment growth. However, findings also reveal that the relationship between employment growth and innovation is not conditioned on firm age but on firm size. Furthermore, employment growth is inversely related to a weak business environment especially among firms that experience electricity outages/ rationing and red tape. Simply put, the relationship between innovation and employment growth is conditioned on the quality of business environment.

Findings also suggest that mechanisms to enhance employment growth in Africa could target incentives aimed at inducing firms to engage in process and product innovations. This is especially so as both process and product innovations are shown to enhance both sales growth and productivity. Also, the effect of sales growth is an increase in the production capacity of firms which implicitly suggests employment growth. Indeed, the paper findings show that employment growth is associated with both process and product innovation as such African governments ought to identify the necessary incentives to induce innovation. 
Table 9 Innovation and productivity

\begin{tabular}{|c|c|c|c|c|c|c|}
\hline & (1) & (2) & (3) & (4) & (5) & (6) \\
\hline & Productivity & Productivity & Productivity & Productivity & Productivity & Productivity \\
\hline \multicolumn{7}{|l|}{ Innov (0 = no innovation) } \\
\hline \multirow[t]{2}{*}{1 (= Process/Product) } & $0.3^{* * *}$ & & & $0.3^{* * *}$ & & \\
\hline & $(0.0588)$ & & & $(0.0613)$ & & \\
\hline \multirow[t]{2}{*}{$2(=$ Process $\times$ Product $)$} & $0.3^{* * *}$ & & & $0.3^{* * *}$ & & \\
\hline & $(0.0580)$ & & & $(0.0616)$ & & \\
\hline \multirow[t]{2}{*}{ Process (1 = yes) } & & $0.3^{* * *}$ & & & $0.3^{* * *}$ & \\
\hline & & $(0.0514)$ & & & $(0.0544)$ & \\
\hline \multirow[t]{2}{*}{ Product (1 = yes) } & & & $0.2^{* * *}$ & & & $0.2^{* * *}$ \\
\hline & & & $(0.0478)$ & & & $(0.0503)$ \\
\hline \multirow[t]{2}{*}{ Retained } & 0.01 & 0.008 & -0.002 & -0.02 & -0.03 & -0.03 \\
\hline & $(0.0699)$ & $(0.0705)$ & $(0.0700)$ & $(0.0731)$ & $(0.0735)$ & $(0.0733)$ \\
\hline \multicolumn{7}{|l|}{ Size (small) } \\
\hline \multirow[t]{2}{*}{ Medium } & $0.2^{* * *}$ & $0.2^{* * *}$ & $0.3^{* * *}$ & $0.2^{* * *}$ & $0.2^{* * *}$ & $0.2^{* * *}$ \\
\hline & $(0.0506)$ & $(0.0508)$ & $(0.0508)$ & $(0.0530)$ & $(0.0532)$ & $(0.0533)$ \\
\hline \multirow[t]{2}{*}{ Large } & $0.6^{* * *}$ & $0.6^{* * *}$ & $0.7^{* * *}$ & $0.6^{* * *}$ & $0.6^{* * *}$ & $0.6^{* * *}$ \\
\hline & $(0.0698)$ & $(0.0701)$ & $(0.0702)$ & $(0.0732)$ & $(0.0734)$ & $(0.0735)$ \\
\hline \multirow[t]{2}{*}{ InAge } & $0.1^{* * *}$ & $0.1^{* * *}$ & $0.1^{* * *}$ & $0.1^{* * *}$ & $0.1^{* * *}$ & $0.1^{* * *}$ \\
\hline & $(0.0321)$ & $(0.0325)$ & $(0.0325)$ & $(0.0331)$ & $(0.0336)$ & $(0.0335)$ \\
\hline \multirow[t]{2}{*}{ InMexperience } & 0.05 & 0.05 & 0.05 & 0.05 & 0.05 & 0.05 \\
\hline & $(0.0346)$ & $(0.0350)$ & $(0.0349)$ & $(0.0356)$ & $(0.0360)$ & $(0.0359)$ \\
\hline \multirow[t]{2}{*}{ Foreign (1 = yes) } & $0.4^{* * *}$ & $0.4^{* * *}$ & $0.4^{* * *}$ & $0.4^{* * *}$ & $0.4^{* * *}$ & $0.4^{* * *}$ \\
\hline & $(0.0650)$ & $(0.0657)$ & $(0.0654)$ & $(0.0677)$ & $(0.0685)$ & $(0.0680)$ \\
\hline \multirow[t]{2}{*}{ Government ( 1 = yes) } & $-0.7^{* * *}$ & $-0.7^{* * *}$ & $-0.7^{* * *}$ & $-0.6^{* * *}$ & $-0.7^{* * *}$ & $-0.7^{* * *}$ \\
\hline & $(0.128)$ & $(0.131)$ & $(0.129)$ & $(0.134)$ & $(0.137)$ & $(0.135)$ \\
\hline \multirow[t]{2}{*}{ Millioncity ( 1 = yes) } & $0.3^{* * *}$ & $0.3^{* * *}$ & $0.3^{* * *}$ & $0.3^{* * *}$ & $0.3^{* * *}$ & $0.3^{* * *}$ \\
\hline & $(0.0510)$ & $(0.0513)$ & $(0.0512)$ & $(0.0526)$ & $(0.0529)$ & $(0.0528)$ \\
\hline \multirow[t]{2}{*}{ Exporting ( 1 = yes) } & $0.1^{*}$ & $0.1^{*}$ & $0.1^{*}$ & $0.1^{*}$ & $0.1^{*}$ & $0.1^{*}$ \\
\hline & $(0.0565)$ & $(0.0569)$ & $(0.0565)$ & $(0.0588)$ & $(0.0591)$ & $(0.0588)$ \\
\hline \multirow[t]{2}{*}{ Electricity } & & & & -0.07 & -0.07 & -0.06 \\
\hline & & & & $(0.0529)$ & $(0.0530)$ & $(0.0532)$ \\
\hline \multirow[t]{2}{*}{ Bureaucracy } & & & & -0.0007 & -0.0005 & -0.0004 \\
\hline & & & & $(0.000949)$ & $(0.000951)$ & $(0.000954)$ \\
\hline \multirow[t]{2}{*}{ Bribe } & & & & $-0.008^{+}$ & $-0.007^{+}$ & $-0.008^{+}$ \\
\hline & & & & $(0.00399)$ & $(0.00404)$ & $(0.00403)$ \\
\hline \multirow[t]{2}{*}{ Competition (1 = yes) } & & & & -0.06 & -0.06 & -0.06 \\
\hline & & & & $(0.0464)$ & $(0.0467)$ & $(0.0465)$ \\
\hline Country fixed effects & Yes & Yes & Yes & Yes & Yes & Yes \\
\hline ISIC fixed effects & Yes & Yes & Yes & Yes & Yes & Yes \\
\hline \multirow[t]{2}{*}{ Constant } & $8.4^{* * *}$ & $8.5^{* * *}$ & $8.5^{* * *}$ & $8.6^{* * *}$ & $8.6^{* * *}$ & $8.7^{* * *}$ \\
\hline & $(0.132)$ & $(0.133)$ & $(0.131)$ & $(0.146)$ & $(0.147)$ & $(0.146)$ \\
\hline N & 5889 & 5824 & 5865 & 5442 & 5386 & 5423 \\
\hline$R^{2}$ & 0.397 & 0.396 & 0.393 & 0.399 & 0.398 & 0.395 \\
\hline Adj. $R^{2}$ & 0.391 & 0.390 & 0.388 & 0.392 & 0.391 & 0.389 \\
\hline
\end{tabular}

Note: (1) All models are pooled OLS with standard errors adjusted for clusters using unique firm identifiers. (2) Standard errors in parentheses. (3) Significance levels: ${ }^{+} p<0.10,{ }^{*} p<0.05,{ }^{* * *} p<0.001$

Source: Authors' own computation based on WBES, 2018 
Table 10 Sales growth and innovation

\begin{tabular}{|c|c|c|c|c|c|c|}
\hline & $(1)$ & $(2)$ & (3) & (4) & (5) & (6) \\
\hline & $\begin{array}{l}\text { Sales } \\
\text { growth }\end{array}$ & $\begin{array}{l}\text { Sales } \\
\text { growth }\end{array}$ & $\begin{array}{l}\text { Sales } \\
\text { growth }\end{array}$ & $\begin{array}{l}\text { Sales } \\
\text { growth }\end{array}$ & $\begin{array}{l}\text { Sales } \\
\text { growth }\end{array}$ & $\begin{array}{l}\text { Sales } \\
\text { growth }\end{array}$ \\
\hline \multicolumn{7}{|l|}{ Innov (0 = no innovation) } \\
\hline \multirow[t]{2}{*}{1 (= Process/Product) } & $0.06^{*}$ & & & $0.07^{*}$ & & \\
\hline & $(0.0274)$ & & & $(0.0289)$ & & \\
\hline \multirow[t]{2}{*}{$2(=$ Process $\times$ Product $)$} & $0.05^{*}$ & & & 0.04 & & \\
\hline & $(0.0266)$ & & & $(0.0271)$ & & \\
\hline \multirow[t]{2}{*}{ Productivity } & $0.1^{* * *}$ & $0.1^{* * *}$ & $0.1^{* * *}$ & $0.1^{* * *}$ & $0.1^{* * *}$ & $0.1^{* * *}$ \\
\hline & $(0.00897)$ & $(0.00886)$ & $(0.00893)$ & $(0.00917)$ & $(0.00904)$ & $(0.00916)$ \\
\hline \multirow[t]{2}{*}{ Process (1 = yes) } & & $0.07^{* *}$ & & & $0.05^{*}$ & \\
\hline & & $(0.0234)$ & & & $(0.0241)$ & \\
\hline \multirow[t]{2}{*}{ Product (1 = yes) } & & & 0.02 & & & 0.01 \\
\hline & & & $(0.0229)$ & & & $(0.0236)$ \\
\hline \multirow[t]{2}{*}{ Retained } & $-0.1^{* *}$ & $-0.08^{*}$ & $-0.1^{* *}$ & $-0.10^{* *}$ & $-0.08^{*}$ & $-0.1^{* *}$ \\
\hline & $(0.0371)$ & $(0.0364)$ & $(0.0373)$ & $(0.0376)$ & $(0.0369)$ & $(0.0379)$ \\
\hline \multicolumn{7}{|l|}{ Size (small) } \\
\hline \multirow[t]{2}{*}{ Medium } & -0.03 & $-0.04^{+}$ & -0.03 & -0.02 & -0.03 & -0.02 \\
\hline & $(0.0240)$ & $(0.0237)$ & $(0.0240)$ & $(0.0251)$ & $(0.0249)$ & $(0.0251)$ \\
\hline \multirow[t]{2}{*}{ Large } & -0.02 & -0.02 & -0.02 & -0.03 & -0.03 & -0.02 \\
\hline & $(0.0371)$ & $(0.0371)$ & $(0.0369)$ & $(0.0389)$ & $(0.0390)$ & $(0.0389)$ \\
\hline \multirow[t]{2}{*}{ InAge } & $-0.03^{* *}$ & $-0.03^{* *}$ & $-0.03^{*}$ & $-0.03^{*}$ & $-0.03^{*}$ & $-0.03^{*}$ \\
\hline & $(0.0134)$ & $(0.0134)$ & $(0.0135)$ & $(0.0132)$ & $(0.0133)$ & $(0.0133)$ \\
\hline \multirow[t]{2}{*}{ InMexperience } & -0.01 & -0.009 & -0.01 & -0.007 & -0.004 & -0.007 \\
\hline & $(0.0162)$ & $(0.0163)$ & $(0.0162)$ & $(0.0168)$ & $(0.0170)$ & $(0.0169)$ \\
\hline \multirow[t]{2}{*}{ Foreign (1 = yes) } & -0.02 & -0.02 & -0.02 & -0.03 & -0.02 & -0.03 \\
\hline & $(0.0278)$ & $(0.0278)$ & $(0.0280)$ & $(0.0285)$ & $(0.0285)$ & $(0.0287)$ \\
\hline \multirow[t]{2}{*}{ Government ( 1 = yes) } & $0.2^{*}$ & $0.2^{*}$ & $0.2^{*}$ & $0.2^{+}$ & $0.2^{+}$ & $0.2^{*}$ \\
\hline & $(0.0822)$ & $(0.0829)$ & $(0.0819)$ & $(0.0855)$ & $(0.0868)$ & $(0.0857)$ \\
\hline \multirow[t]{2}{*}{ Millioncity (1 = yes) } & -0.02 & -0.03 & -0.03 & -0.02 & -0.03 & -0.02 \\
\hline & $(0.0254)$ & $(0.0250)$ & $(0.0254)$ & $(0.0259)$ & $(0.0257)$ & $(0.0260)$ \\
\hline \multirow[t]{2}{*}{ Exporting ( 1 = yes) } & -0.006 & -0.006 & -0.0007 & 0.004 & 0.003 & 0.006 \\
\hline & $(0.0286)$ & $(0.0286)$ & $(0.0285)$ & $(0.0296)$ & $(0.0297)$ & $(0.0298)$ \\
\hline \multirow[t]{2}{*}{ Electricity ( 1 = yes) } & & & & -0.02 & -0.02 & -0.02 \\
\hline & & & & $(0.0266)$ & $(0.0264)$ & $(0.0267)$ \\
\hline \multirow[t]{2}{*}{ Bureaucracy } & & & & $-0.0009^{*}$ & $-0.0008^{*}$ & $-0.0008^{*}$ \\
\hline & & & & $(0.000406)$ & $(0.000406)$ & $(0.000408)$ \\
\hline \multirow[t]{2}{*}{ Bribe } & & & & $0.003^{+}$ & $0.003^{+}$ & $0.003^{+}$ \\
\hline & & & & $(0.00192)$ & $(0.00195)$ & $(0.00193)$ \\
\hline \multirow[t]{2}{*}{ Competition } & & & & -0.01 & -0.005 & -0.008 \\
\hline & & & & $(0.0223)$ & $(0.0223)$ & $(0.0224)$ \\
\hline Country fixed effects & Yes & Yes & Yes & Yes & Yes & Yes \\
\hline ISIC fixed effects & Yes & Yes & Yes & Yes & Yes & Yes \\
\hline
\end{tabular}


Table 10 Sales growth and innovation (Continued)

\begin{tabular}{lllllll}
\hline & $(1)$ & $(2)$ & $(3)$ & $(4)$ & $(5)$ & $(6)$ \\
& $\begin{array}{l}\text { Sales } \\
\text { growth }\end{array}$ & $\begin{array}{l}\text { Sales } \\
\text { growth }\end{array}$ & $\begin{array}{l}\text { Sales } \\
\text { growth }\end{array}$ & $\begin{array}{l}\text { Sales } \\
\text { growth }\end{array}$ & $\begin{array}{l}\text { Sales } \\
\text { growth }\end{array}$ & $\begin{array}{l}\text { Sales } \\
\text { growth }\end{array}$ \\
\hline Constant & $-0.8^{* * *}$ & $-0.8^{* * *}$ & $-0.8^{* * *}$ & $-0.9^{* *}$ & $-0.9^{* * *}$ & $-0.9^{* * *}$ \\
$N$ & $(0.0964)$ & $(0.0970)$ & $(0.0964)$ & $(0.102)$ & $(0.102)$ & $(0.102)$ \\
$N$ & 5822 & 5762 & 5798 & 5389 & 5337 & 5370 \\
$R^{2}$ & 0.118 & 0.116 & 0.117 & 0.121 & 0.119 & 0.120 \\
Adj. $R^{2}$ & 0.109 & 0.108 & 0.109 & 0.111 & 0.110 & 0.110 \\
\hline
\end{tabular}

Note: (1) All models are pooled OLS with standard errors adjusted for clusters using unique firm identifiers. (2) Standard errors in parentheses. (3) Significance levels: ${ }^{+} p<0.10,{ }^{*} p<0.05,{ }^{* *} p<0.01,{ }^{* * *} p<0.001$

Source: Authors' own computation based on WBES, 2018

Furthermore, this paper was able to establish that a weak business environment characterized by, for example, poor quality public infrastructure (as proxied by electricity supply) undermines the ability of product and process innovations to induce employment growth. Thus, findings lay emphasis on the importance of coordination between public services and private sector investment. In essence, private sector investment is rendered suboptimal in the midst of inadequate public services. As such, analysis suggests that African governments ought to strengthen the quality and quantity of public infrastructure as these have the ability to enable firms to optimize the benefits of innovation with the ultimate effect being employment growth.

\section{Endnotes}

${ }^{1}$ http://www.worldbank.org/en/news/speech/2017/11/30/innovation-in-africa

${ }^{2}$ Process innovation refers to any new or significantly improved methods of manufacturing products or offering services; logistics, delivery, or distribution methods for inputs, products, or services; or supporting activities for processes.

${ }^{3}$ Product innovation on the other hand refers to introduction of new or significantly improved products.

${ }^{4}$ In our paper, process innovation by definition includes organisational innovation.

55 To mean innovation is destructive to employment.

${ }^{6}$ Ethiopia, Burundi, Uganda, Tanzania, Rwanda, Kenya, Democratic Republic of Congo (DRC), Djibouti, Egypt, Cameroon, Central African Republic (CAR), Ivory Coast, Ghana, Guinea, Tunisia, Zambia, Sudan, Swaziland, Lesotho, Malawi, Mauritania, Mali, Morocco, Namibia, Senegal, Nigeria and Niger

${ }^{7}$ For a detailed explanation about the sample methodology and questionnaire used in data collection, please refer to http://www.enterprisesurveys.org/methodology

${ }^{8}$ Cannibalism is a term in the innovation-employment growth literature to mean that innovation is associated with employment destruction to the extent that employment growth is undermined.

${ }^{9}$ For comparability across countries, we convert sales into US dollars using the average exchange rate of the year in which the survey was undertaken.

${ }^{10}$ This is consistent with Griffith et al. (2006), Lööf and Heshmati (2006), and Van Leeuwen and Klomp (2006) who show that firm productivity is increasing among firms that innovate.

${ }^{11}$ In this paper, organisational innovation is part of process innovation. 
Abbreviations

IV 2SLS: Instrumental variable two-stage least squares; MENA: Middle East and North African; OLS: Ordinary least squares; R\&D: Research and development; SSA: Sub-Saharan Africa; SYS GMM: System generalized method of moments; WBES: World Bank Enterprise Survey

\section{Funding}

My co-authors and I did not receive any funding towards writing this manuscript.

Availability of data and materials

We used the World Bank Enterprise Survey data for Africa. This is readily available upon request. Please note, we can also avail the do files upon request.

\section{Authors' contributions}

This paper was jointly conceived, developed and written by Prof. EB and Dr. MMG (my co-authors) and I. All authors read and approved the final manuscript.

\section{Authors' information}

Ibrahim Mike Okumu is an academic with research interest in public finance, informal economy, inequality, economic growth, economic development and public sector governance. His research experience has involved understanding the integral role of an effectively functioning public sector on: private sector development; quality of public expenditure; tax evasion; informal economy; and income inequality. My research output has appeared in among others South African Journal of Economics and African Journal of Economic review. I am currently using World Bank Enterprise Survey to write different papers about the response of firms to the business environment in Africa. Otherwise, Dr. Okumu is currently a Senior Lecturer at the School of Economics, Makerere University. He is also an Associate Researcher at the Economic Policy Research Center, Makerere University and a Research Affiliate of the Centre for Dynamic Macroeconomic Analysis, University of St Andrews. Dr. Okumu holds a PhD in Economics of the University of St Andrews (United Kingdom), MA Economics of McMaster University (Canada) and BA Economics of Makerere University (Uganda).

Edward Bbaale is an Associate Professor of Economics and holds a PhD in Economics, M.A. Economic Policy and Planning and B.A. Economics among other qualifications. Edward is also currently the Dean of the School of Economics, Makerere University. At national level, he has coordinated a number of projects aimed at informed policy making, formulation, analysis and advocacy. Edward has written over 20 papers, published in peer reviewed journals, using survey data obtained from secondary sources (especially the World Bank Enterprise Surveys, UNIDO data sets, UDHS, UNHS among others) and from own primary survey undertaken on enterprises across the country. Edward, therefore, has very rich hands on experience in handling huge survey data sets. At a macro level, Edward has undertaken cross-country studies. One of his papers that used enterprise data, published in the African Journal of Economics and Management Sciences, was voted as a Highly Commended Award Winner at Literati Network Awards for Excellence 2012 (http://www.emeraldinsight.com/literati). In addition to enterprise surveys, Edward has also undertaken several household surveys that resulted into various consultancy reports and papers.

Madina Mwagale Guloba is a development economist, with a PhD and Masters of Arts in Economics from University of Dar es Salaam, Tanzania under the Collaborative Postgraduate Programme of the African Economic Research Consortium (AERC), Nairobi-Kenya. Madina is currently a Senior Research Fellow at the Economic Policy Research Centre (EPRC). She has more than nine years of research experience in which she has worked on several projects and published in the field of development economics, gender, climate change, education, environment, natural resources and labour markets. Madina is a member of the International Association of Feminist Economist (IAFFE), AERC alumni, member of the National Advisory Committee on Monitoring and Evaluation and member of the Evaluations SubCommittee. She is also a member of the Uganda Statistical Society.

\section{Competing interests}

Prof. Edward Bbaale and Dr. Madina Mwagale Guloba (my co-authors) and I wish to categorically state that we have no competing interests whether financial or non-financial regarding our paper titled: Innovation and employment growth: evidence from manufacturing firms in Africa.

\section{Publisher's Note}

Springer Nature remains neutral with regard to jurisdictional claims in published maps and institutional affiliations.

\section{Author details}

${ }^{1}$ School of Economics, Makerere University, Kampala, Uganda. ${ }^{2}$ Economic Policy Research Center, Makerere University, Kampala, Uganda.

Received: 6 August 2018 Accepted: 13 February 2019

Published online: 05 March 2019

\section{References}

Aboal, D., Garda, P., Lanzilotta, B., \& Perera, M. (2015). Innovation, firm size, technology intensity, and employment generation: evidence from the Uruguayan manufacturing sector. Emerging Markets Finance and Trade, 51(1), 3-26.

Aghion, P., \& Akcigit, U. (2017). Innovation and growth: The Schumpeterian perspective. In L. Matyas (Ed.), Economics without Borders, Chapter (Vol. 1, pp. 29-72). Cambridge University Press.

Aghion, P., \& Howitt, P. (1992). A model of growth through creative destruction. Econometrica, 60(2), 323-351. 
Aterido, R., and M. Hallward-Driemeier, (2010). The impact of the investment climate on employment growth: does subSaharan Africa mirror other low income regions? The World Bank, policy research working paper, 5218.

Aterido, R., Hallward-Driemeier, M., Page's C. (2011). Big constraints to small firms' growth? Business environment and employment growth across firms. Economic Development and Cultural Change, 59(3), 609-647.

Benavente, J. M., \& Lauterbach, R. (2008). Technological innovation and employment: complements or substitutes? The European Journal of Development Research, 20(2), 318-329.

Bhaumik, S. K., Estrin, S., \& Meyer, K. (2007). Determinants of employment growth at MNEs: evidence from Egypt, India, South Africa and Vietnam. Comparative Economic Studies, 49(1), 61-80.

Bogliacino, F., Piva, M., \& Vivarelli, M. (2012). R\&D and employment: an application of the LSDVC estimator using European microdata. Economics Letters, 116(1), 56-59.

Cirera, X. and L. Sabetti, (2016). The effects of innovation on employment in developing countries: evidence from enterprise surveys World Bank, policy research working paper no. 7775

Coniglio, N. D., Prota, F., \& Seric, A. (2015). Foreign direct investment, employment and wages in sub-Saharan Africa. Journal of International Development, 27(7), 1243-1266.

Dachs, B., \& Peters, B. (2014). Innovation, employment growth, and foreign ownership of firms a European perspective. Research Policy, 43(1), 214-232.

Davis, S. J., \& Haltiwanger, J. (1992). Gross job creation, gross job destruction, and employment reallocation. Quarterly Journal of Economics, 107(3), 819-863.

Davis, S. J., \& Haltiwanger, J. (1999). On the driving forces behind cyclical movements in employment and job reallocation. American Economic Review, 89(5), 1234-1258.

Elejalde, R., Giuliodori, D., and R. Stucchi. (2015). Employment and Innovation: Firm-Level Evidence from Argentina. Emerging Markets Finance \& Trade, 51(1), pp. 27-47.

Evangelista, R., \& Vezzani, A. (2012). The impact of technological and organizational innovations on employment in European firms. Industrial and Corporate Change, 21(4), 871-899.

Fukao, K., Keuchi, K., Kim, Y. G., \& Kwon, H. U. (2017). Innovation and employment growth in Japan: analysis based on microdata from the Basic Survey of Japanese Business Structure and Activities. Japanese Economic Review, 68(2), $200-216$.

Greenan, N., \& Guellec, D. (2000). Technological innovation and employment reallocation. Labour, 14(4), 547-590.

Griffith, R., Huergo, E., Mairesse, J., \& Peters, B. (2006). Innovation and productivity across four European countries. Oxford Review of Economic Policy, 22(4), 483-498.

Harrison, R., Jaumandreu, J., Mairessee, J., \& Peters, B. (2014). Does innovation stimulate employment? A firm-level analysis using comparable micro-data from four European countries. International Journal of Industrial Organization, 35, 29-43.

Lachenmaier, S., \& Rottmann, H. (2011). Effects of innovation on employment: a dynamic panel analysis. International Journal of Industrial Organization, 29(2), 210-220.

Lööf, H., \& Heshmati, A. (2006). On the relationship between innovation and performance: a sensitivity analysis. Economics of innovation and new technology. In 15 (4/5): 317-344; special issue 'on empirical studies of innovation in the knowledge driven economy'.

Meriküll, J. (2010). The Impact of Innovation on Employment: Firm and Industry-Level Evidence from a Catching-Up Economy. Eastern European Economics, 48(2), 25-38

Naudé, W., A. Szirmai and M. Goedhuys, (2011). Innovation and entrepreneurship in developing countries United Nations University policy brief no. 1

Nickell, S. (1999). Product markets and labour markets. Labour Economics, 6, pp. 1-20

Peters, B. (2004). Employment effects of different innovation activities: microeconometric evidence. ZEW discussion paper no. 0473, ZEW Mannheim.

Piva, M., \& Vivarelli, M. (2004). Technological change and employment: some micro evidence from Italy. Applied Economics Letters, $11(6), 373-376$

Piva, M., \& Vivarelli, M. (2005). Innovation and employment: evidence from Italian microdata. Journal of Economics, 86(1), 65-83.

Van Leeuwen, G., and Klomp L., (2006). On the contribution of innovation to multi-factor productivity growth. Economics of Innovation and New Technology, 15 (4/5): 367-390; Special Issue 'On Empirical Studies of Innovation in the Knowledge Driven Economy'.

Van Reenen, J. (1997). Employment and technological innovation: evidence from U.K. manufacturing firms. Journal of Labour Economics, 15(2), 255-284.

\section{Submit your manuscript to a SpringerOpen ${ }^{\circ}$ journal and benefit from:}

- Convenient online submission

- Rigorous peer review

- Open access: articles freely available online

- High visibility within the field

- Retaining the copyright to your article

Submit your next manuscript at $>$ springeropen.com 